\section{E- LOGOS}

ELECTRONIC JOURNAL FOR PHILOSOPHY ISSN 1211-0442

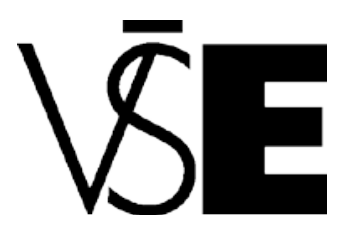

University of Economics Prague

The meaning of life together and inter-relationship in business

Maciej Bazela

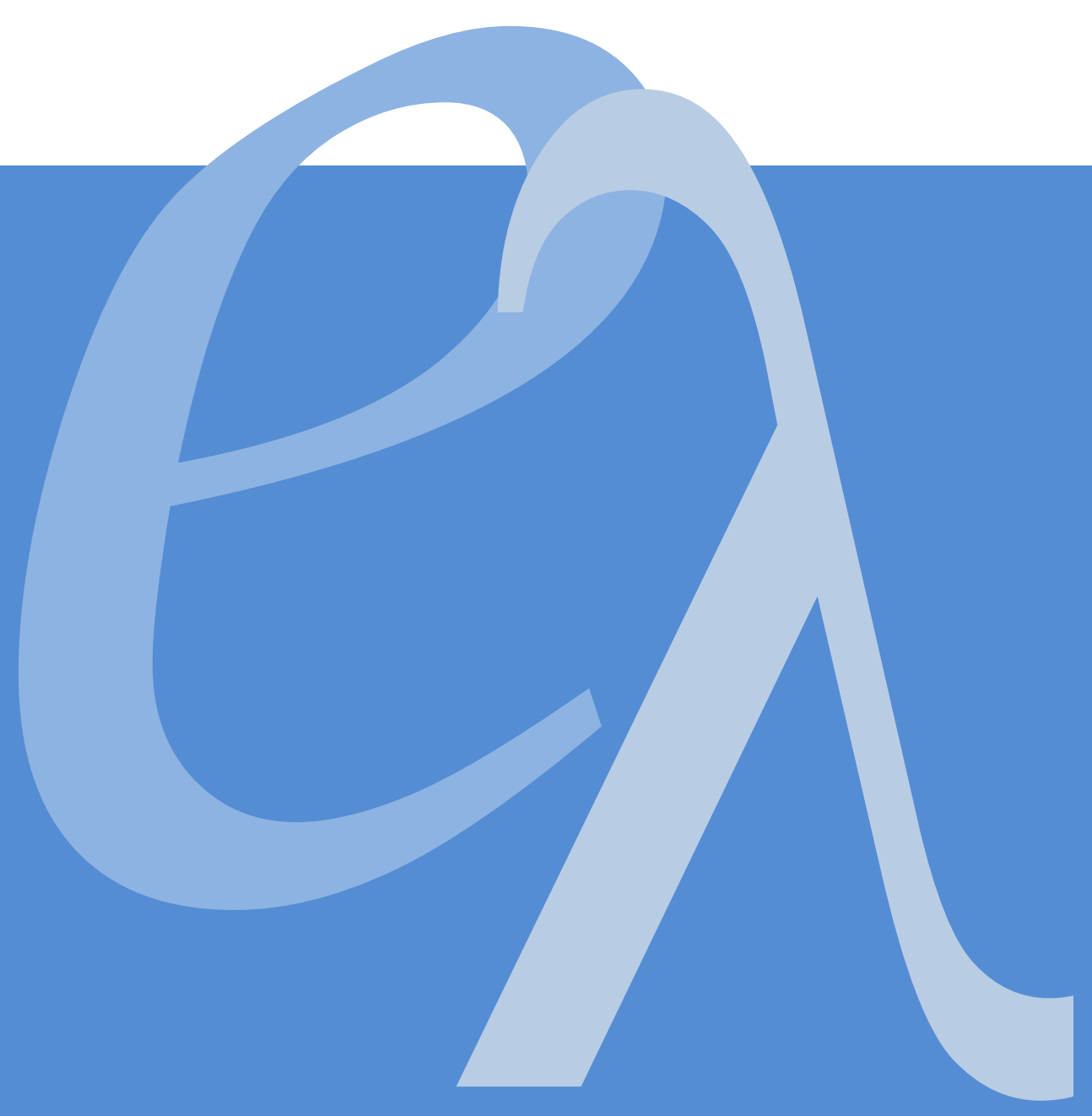




\begin{abstract}
The author argues that life together and inter-relationship are extremely important values in business, supposing we accept John Paul's II vision of business enterprise as "community of persons". Since firms are principally made of people and called to serve people, the ultimate purpose of business is nothing else but integral human development. Consequently, companies ought to act upon the ideals of life together and interrelationship by taking the road of social and environmental responsibility. The values of life together and (symbiotic) interrelationship turn into three major tasks for business: a) care for employees; b) care for local communities; c) care for the environment. Corporate exuberance seems indissoluble linked to welfare of local communities. This is why firms should have an interest in promoting symbiotic life together and mutually beneficial interrelationships with various stakeholders. The article aims to provide some examples of what care for employees, communities and the environment may mean in practice.
\end{abstract}

Keywords: corporate social and environmental responsibility, workers' empowerment, employability, work-life balance policies, social capital, ecoefficiency, bio-imitation, cradle-to-cradle economy. 
"A company's profits or activities are not goals that can be viewed in isolation from other considerations. Economic activities also require an ethical foundation that puts people, the environment and broader social considerations centre stage." 1

In September 2009 we could ready in the news about a wave of suicides at France Télécom, a French telecommunication company. In eighteen months as many as 23 employees of decided to kill themselves in response to organizational changes within the company. It is believed that the wave of suicides was an extreme personal response to extreme top-down management pressures, overwhelming stress, and draconian restructuring policies. ${ }^{2}$ Sadly, the case of France Télécom is not separated since in the same period of time also three traders of Société Generale, a French bank, killed themselves because of too high bank's expectations to deliver results. ${ }^{3}$ Also, in April 2009, David Kellermann, the chief financial officer of Freddie Mac committed suicide while the company was under criminal investigation regarding accounting irregularities and huge financial losses generated by sub-prime mortgages and other derivative investment instruments.

Although it would be probably stretched to draw far-reaching and universal conclusions from single episodes of human tragedy, I think that the abovementioned shocking events within the business world invite us to interrogate ourselves about what may happen at work when such values as the dignity of the human person, primacy of the human capital over finance, solidarity, and team spirit are overshadowed by the expectation of ever-rising profit and efficiency at any coast.

My aim in this article is to argue that life together and inter-relationship are extremely important values in business, supposing we accept John Paul's II vision of business enterprise as "community of persons". In his encyclical Centesimus Annus, the pope states that "the purpose of a business firm is not simply to make a profit, but is to be found in its very existence as a community of persons who in various ways are endeavouring to satisfy their basic needs, and who form a particular group at the service of the whole of society. Profit is a regulator of the life of a business, but it is not the only one; other human and moral factors must also be considered which, in the long term, are at least equally important for the life of a business." 4

\footnotetext{
1 The Norwegian Ministry of Foreign Affairs, Corporate social responsibility in a global economy. Report no. 10 (2008-2009) to the Storting (Oslo, 2009), 6.

2 Cf. Max Colchester, "France Télécom addresses suicides", New York Times, http://online.wsj.com/article/SB125291498468308169.html; "French uneasy at Télécom suicides", http://news.bbc.co.uk/2/hi/8252547.stm [Retrieved 28-10-2009].

3 Cf. Astrid Wendlandt, "SocGen suicides put stress at work under spotlight", http://www.reuters.com/article/topNews/idUSL2982685920080129 [Retrieved 28-10-2009].

${ }^{4}$ John Paul II, Encyclical Letter Centesimus Annus (Vatican City, 1991), n. 35.
} 
In other words, corporations are not money machines, nor mere manufactures of goods, but should be seen as human endeavour, a joint effort to improve human life conditions. Firms are by its nature inter-related entities inasmuch as business is about constant networking and interacting with various stakeholders- owners, investors, employees, suppliers, customers and society at large. Since firms are principally made of people and called to serve people, the ultimate purpose of business is nothing else but integral human development. That at least seems to be the moral core of economic life according to Benedict's XVI latest Encyclical Letter Caritas in veritate.

Consequently, I would like to argue that companies can and probably ought to act upon the ideals of life together and interrelationship by up taking the road of social and environmental responsibility. The distinction between can and ought to is not casual here. From the utilitarian point of view, corporate responsibility for human and environmental costs of business turns out to be a mere matter of enlightened selfinterest - a means to higher profits and more competitive edge. From the personalist Catholic angle, however, corporate responsibility is a moral calling that finds its roots in the acceptance of the intrinsic dignity of the human person, the social nature of man, the universal destination of goods and stewardship of the environment.

Seen from a Catholic perspective, corporate social responsibility means a conscientious management that promotes the values of life together and (symbiotic) interrelationship in business through a constant carrying out of the three following tasks: a) care for employees, b) care for local communities, c) care for the environment.

\section{Care for employees.}

A wide-range consensus exists on the idea that human capital is the most precious factor of corporate success. No matter how much financial capital you may have, you cannot achieve great outcomes without creative, efficient and committed staff who will transform that capital into ideas, processes and products. Yet, creativity, efficiency and commitment of employees should not be taken for granted, nor should they be treated as infinite resource that will never disappear. To the contrary, employees' dedication and skills wane when they are not cultivated, supported and rewarded. For this reason, it is important that companies invest in human capital and the work environment because satisfied employees pay back by greater commitment, higher productivity and lower absenteeism. Corporate investment in human capital embraces a wide gamut of initiatives that are tailored to (1) empower employees, (2) boost career prospects, (3) bridge the gap between professional and private life, and (4) improve working conditions. 
(1) Workers' empowerment can be achieved by shared ownership schemes, participation in company's decision-making process and profit-sharing. It seems just to share proportionately in the fruit of wealth that one has a hand in creating. Whoever is cause of profit should receive proportionate remuneration.

Another source of workers' empowerment is a vast presence of small and middlesize business establishments. When the market is not in hands of a few megacorporations, then the know-how, technologies and other resources can more easily penetrate to all social pockets energizing them and entrenching self-government. A relatively flat structure of the business world creates a positive climate for the spread of entrepreneur skills, individual responsibility and economic autonomy. Job positions in small, self-managing units are usually more active and stimulating. The substantial difference between being an ant-worker in a giant company or a protagonist in a small business is similar to a difference between living in a proper house or a block of flats. To have a house is thoroughly empowering and energizing experience since you feel directly responsible for it and at the same time you want to be proud of it. Certainly, you manage to create a holistic view of your property. You know pretty well its every corner and constantly plan how to make a perfect use of them. Nevertheless, your house still is big and complex enough that you are never bored with it. There always is something new that you discover or learn about it. Having a house is a non-stop affair, because there always is something to fix, refresh or redesign. Since there is no one but you to take care of it, you constantly learn new skills, and your know-how and creativity expand. You feel to be a craftsman who never ceases to refine his products.

In contrast, living in a block of flats is totally different experience. Not only does it not stimulate you, but also you entrench a sense of isolation and indifference towards the outdoors. Life in an apartment may be very cosy, but dreary at the same time. Although you like and know your flat very well, the rest of the building- and probably other residents- represent a corpum alienum. Block of flats is "easy" to live in and yet undemanding. It is sedative and dehumanizing, for it impinges your human potential. Your creativity is limited to your flat, and even there you may find many restrictions that will not allow you to design your space as you really would desire.

A flat will always remain a pre-packed semi-defined consumer product that you can buy and use up. A house however means much more than a good. A house is a fruit of your imagination and craft efforts, it is your creation that you craft from beginning to end. In my opinion, the same scenario applies to small business (house) and elephantine corporation (block of flats).

(2) As far as career prospects are concerned, the European Union Green Paper on corporate social responsibility underlines that "companies should take up their share 
of responsibility to ensure the employability of their staff". ${ }^{5}$ The concept of employability is particularly relevant in the context of the great flexibility of today's labour market. When the underlying trend is to replace permanent employment with temporary and ad hoc assignments, workers must be capable of changing jobs at any time during their professional life. The Green Paper reminds us that "restructuring in a socially responsible manner means to balance and take into consideration the interests and concerns of all those who are affected by the changes and decisions". ${ }^{6}$ Employability calls for such a management of human resources which enables redundant workers to find job elsewhere, which is more likely only if companies offer life-long learning and training opportunities. It is a corporate social burden to provide their staff with on-going professional formation through apprenticeships, accreditation, away sessions, business trips, updating seminars or even in-house university courses. Not only does it improve future employability, but also fosters productivity and creativity at a current work place.

Knowing also that the global economy is becoming prevailingly knowledgedriven, providing continuous learning and training opportunities is vital for companies to keep the best talent.

Employability is becoming the contemporary counterpart of job security and professional stability. According to one survey, today's employees no longer expect guaranteed job positions for life. However, they presume that employers will help them keep their skills up to date. ${ }^{7}$ Evidently, "the key to solid economic growth, stable employment and rewarding jobs [...] will come down to one thing - lifelong education. The best firms should have the best training opportunities. Lifelong education and continuous improvement of skills may soon be the only chance to keep a plant/firm competitive, so it is in the shared interests of executives and unions that workers update their skills that relate directly to their jobs, but also deepen their knowledge in areas of IT, advanced computers, communication, HR and math". 8

Therefore, it could be a good idea that classes take place at company's premises during working-hours. From my point of view, such an arrangement would be a strong incentive to participate in training sessions and take real advantage of them. Today however workers are usually forced to upgrade their skills at their own expense and sacrifice their free-time, which are unfavourable conditions.

\footnotetext{
5 The European Commission, Directorate General for Employment and Social Affairs, Promoting a European framework for corporate social responsibility - Green Paper (Luxembourg, 2001), 11.

6 The European Commission, Directorate General for Employment and Social Affairs, Promoting a European framework for corporate social responsibility - Green Paper (Luxembourg 2001), 11.

${ }^{7}$ Cf. "The battle for brainpower. A survey of talent", The Economist 40 (7th-13 th October 2006).

${ }^{8}$ David Kidwell, "How to succeed with $21^{\text {st }}$ century work force", Centre for Ethical Business Culture, University of Minnesota, Carlson School of Management, First Tuesday Speech, 6 March 2001, http://cebcglobal.org/Publications/WorkLife/Kidwell.htm [Retrieved 09-01-2006].
} 
There is also a need for greater mobility between particular departments within companies. Interdisciplinary work and stronger co-operation between particular units would create opportunities to learn new skills and make atomized roles more complex and thereby more interesting. Employees in entry or middle-rank positions should be able to "travel across" different departments to find out how the company works. Internal courses could be offered through which interested workers would get certificates to move from one department to another. In that way we would move from one-role employee concept to multitask employee who is capable of undertaking various tasks within the same structure.

Corporations could establish partnerships and elaborate common standards that enable employee exchange. Similarly to Socrates-Erasmus program, which is the European Union's initiative for student exchange that allows you to complete a part of your academic curriculum as a visiting student at another university, there could be a corporate Socrates-Erasmus that would allow workers to get some experience in a partner company or a foreign branch of your own brand.

To give one example of investment in employability, Grupo Ferrovial, a worldwide known Spanish construction company, opened Summa- Ferrovial's Corporate University. The University consists of three schools: (1) the Leadership School, which aims to develop management skills; the Business School, which offers specialised training in different fields of management; and the Cultural Integration School, which focuses on language programs and cultural integration. ${ }^{9}$

(3) In addition, supplementary training in such areas as interpersonal communication, team-work, conflict resolution, stress management is not only helpful at work, but can also improve workers' ability to handle their family roles as parents and spouses at home. Corporate success and workers' well-being are undeniably rooted in a constructive and happy family/private life. There is a mutual reinforcement between professional life and private life which makes difficult situations in one of these spheres generate problems in others. Similarly, success at work brings more serenity home; satisfactory personal life stimulates creativity at work. Therefore, the corporate duty should be to adopt such management solutions that neutralize artificial bifurcation between these two spheres and release unnecessary tension between them. This goal can be furthered with familydesignated social benefits such as flexible work schemes, pro-family benefits, economic incentives and on site services. ${ }^{10}$

\footnotetext{
9 Cf. http://www.ferrovial.es/en/index.asp?MP=17\&MS=637\&MN=2\&TR=C\&IDR=2055 [Retrieved 06-11-2009].

10 An extensive review of work-life balance policies by Fidelis International Institute for Business Ethics has revealed that companies tend to bridge the gap between professional and private life of employees through worker flexibility, family benefits and in-house special services.
} 
(4)Finally, the improvement of working conditions implies the amelioration of the interpersonal atmosphere and renovation of work premises according to sustainable and healthy design standards.

Robert C. Solomon claims in his theory of business excellence that corporations should form genuine communities, because it improves performance. "Corporations are not abstractions or monoliths; they are real communities of people working together [...]. Corporations are neither legal fictions nor financial juggernauts but communities of people working together for the common good [...]. A corporation is not an abstraction called 'the profit motive', but the will and ambitions of its employees [...]. Corporation is not a collection of individuals, because the individuals are created by the corporation and the corporation is more than just a sum of individuals". 11

Relying on the Aristotelian premise that man is social by nature and community is a key factor for human development, companies are supposed to establish corporate cultures, for "a culture is first of all a structured community of individuals and their interrelationships". ${ }^{12}$ Providing that business enterprise is a community of people, creation of a coherent, transparent and integral corporate culture is indispensable for success, since what keeps communities afloat is shared values and goals. "With [this] emphasis on integrity and community comes not only the fulfilment of obligations to stockholders [...] but the production of quality and the earning of pride in one's product, providing good jobs and well-deserved rewards for employees, and the enrichment of a whole community and not just a select group of contracted owners". 13

Worker flexibility regards all kinds of employment schemes which differ from the traditional fulltime job with a permanent contract. The flexible aspect of these types of jobs can concern location (e.g. working from home, working on the move, working from telecenters), time (e.g. compressed hours, part-time job, job sharing, annualised hours), or contract (e.g. casual labour, outsourcing, temporary work, fixed term assignments).

Family benefits usually consider either child bearing (e.g. paternity and maternity leave, phased return from maternity leave), child rearing (e.g. child allowances, on site kindergartens, unpaid leave during school days, childcare voucher schemes, paid religious holidays, late hour policies, family relocation policies, seminars on family issues), or financial stability of families (e.g. life insurance, retirement plan, family bonus).

The category of in-house special services include all sorts of amenities and resources like gyms, fitness centres, dry cleaning points, cash machines, mini-markets that corporations put in place to help employees sort out daily routines without wasting time on commuting to different sites.

${ }^{11}$ Robert C. Solomon, Ethics and excellence. Co-operation and integrity in business (New York - Oxford: Oxford University Press, 1993), 9.109.150.152

12 Robert C. Solomon, Ethics and excellence..., 129.

${ }^{13}$ Robert C. Solomon, Ethics and excellence..., 109. 
Solomon points out that personal excellencies- traits and characteristics that enable people to fulfil their professional, social and family roles- can surface only if individuals are embedded in communities; when they can fall back on acknowledged moral standards and deontological codes of conduct. Virtuous individuals are a priceless asset. Therefore, there is nothing more important for companies than the development of corporate culture, since investing in a positive work ambience and enriching interpersonal relationships means investing in your own success. Even though the balance of power is shifting from companies to workers (growing number of freelancers and free agents, especially among computer experts, top executives, managers, sports stars and actors), well-run corporationsunderstood as a community of people and a work environment- are repositories of skills that are hard to replicate. Talent may reside in the brains of individuals, but it is also nurtured by organization. ${ }^{14}$

\section{Care for local communities.}

A simple reason for which companies should be interested in the well-being of local communities is that business cannot be successful in societies that fail. Firms encounter great difficulties operating in socio-political realities where the government is corrupt and weak, private property not respected, citizens poorly educated and lacking moral spine. ${ }^{15}$ Firms do not operate only on the market, but also within local communities, cultures and political systems. ${ }^{16}$ Markets are not isolated from societies and cultures, but embedded in them. Therefore, there is a mutually reinforcing dependence between the well-being of local communities and corporate success. The weaker are social and political institutions (the family, the government, the health care, the education), the more dismal is corporate performance. The stronger are these social institutions, the more productive are companies.

Companies then have a clear incentive to support local communities as much as their success depends on the health of social entities.

A paramount example of this philosophy of business comes from Deutsche Bank which perceives its pro publico bono activity as investment in the future of the company and in the future of the communities where the company is present. For the bank, social responsibility is not only a strategy for risk and reputation management, but primarily a way of building social capital without which we can have neither thriving societies, nor prosperous business.

\footnotetext{
${ }^{14}$ Cf., “The battle for brainpower...".

15 Cf. Peter George, "Making business moral", The First Things 186 (October 2008): 17-19.

${ }^{16}$ Cf. The Norwegian Ministry of Foreign Affairs, Corporate social responsibility in a global economy..., 6.
} 
As explained by the bank's business expert, "ccorporate social responsibility is about helping companies and society alike. It is about creating conditions for mutual, sustainable advancement. From a company perspective, an investment that benefits society benefits everyone. Understanding, practicing, and justifying social responsibility in an environment of global competition is only imaginable and achievable as a win-win model [...]. The long-term success of companies can only be achieved in well-developed societies with social capital and diversified networks [...]. Societies are strong when they have stable, reliable internal structures. Dictators have always sought to destroy such structures in an effort to crush resistance that they fear could emerge from organized, networked groups. The stability and diversity of networks is essential to strong societies, as are communication, transparency, and the active participation of broad sections of the populace in society requiring at least a minimum level of education and wealth. Enabling and strengthening the independence of citizens and their own sense of responsibility is equally important. Social responsibility viewed as such encourages companies to become involved in various areas, such as corporate volunteering and promoting education, culture, and health initiatives, and to participate in social and political discussions." 17

In particular, the bank seeks to build social capital by creating opportunities (social investment), fostering creativity (arts) and enabling talent (education).

As far as social investment is concerned, the bank uses its key competence to empower societies through microfinance instruments and social venture funds. ${ }^{18}$ The bank collaborates with more than 100 micro-lending institutions that help people escape from the vicious circle of poverty and deprivation by purchasing land, establishing small stores or buying farm animals. The bank supports also social venture organisations such as Ashoka, The Eye Fund, E+Co, NewGlobe Schools and Seedco Fisheries Assistance Centre that develop economically sound and socially emancipating solutions in healthcare, education and entrepreneurship.

Moreover, "DB Supportive Housing Acquisition and Rehabilitation Effort" is a Deutsche Bank initiative in New York that has created more than 2,000 new living units in order to ease the homeless problem.

In Peru, where more than half the population lacks access to water, Deutsche Bank supports Agualimpia which brings potable water and sanitation systems to isolated rural villages.

In addition, Deutsche Bank fosters community development through cultural and educational initiatives. For example, the Americas Foundation of Deutsche Bank,

${ }^{17}$ Karl Homann, "Corporate social responsibility in transition", http://www.db.com/csr/en/content/7528.htm [Retrieved 11-11-2009].

${ }^{18}$ Cf. http://www.db.com/csr/en/content/7327.htm [Retrieved 11-11-2009]. 
with its "Arts and Enterprise" program organises art exhibitions in poor city neighbourhoods and art training for disadvantaged children and young people.

The "Compass of Studies" is an initiative that helps young people pursue a university degree. The program was founded in 2007 by Deutsche Bank Foundation together with the Accenture Foundation and the Foundation of German Business.

Since music and arts stimulate human intellect, the bank established also many joint venture projects with museums, concert halls and art galleries and foundations to diffuse cultural education. For the moment, the bank works with such institutions as the Berliner Philharmoniker, Shakespeare's Globe Theatre, Zacheta National Gallery, Solomon R. Guggenheim Foundation and many others. ${ }^{19}$

All in all, the bank undertakes all this initiatives because it understands that its sustainable corporate future is contingent on social capital- creativity, flexibility, viability, dynamism and stability of communities. Firms and societies are interrelated and mutually dependent on each other. They either thrive or decline together. As stated by the banks CEO, "the current [financial] crisis has clearly shown that companies do not operate in a vacuum. They are part of society. And the more stable the social environment, the better their chances of success. It is therefore in our own interests to invest in social stability and prosperity, for our own benefit and for the benefit of society as a whole, on a globe scale." 20

\section{Care for the environment.}

In the third place, corporate future is also strongly inter-related to and dependent on the environment. As corporations cannot function well without social capital, so they cannot do without natural resources. Even though we may tend to think about man's economic activity in terms of production, consumption, profits and stocks, we cannot ignore a biophysical dimension of economic activity. The human economy "does not exist in void, but it is a subsystem of the finite biosphere that supports it" $^{21}$ When we think about economy, we should take into account that its functioning is contingent on availability of raw materials of an eco-sphere that has limited volume and capacities. The economy is a sub-division of the finite biosphere, which is a non-growing and materially closed system that sets limits to our economic performance. The finiteness of nature is triple: (1) there is a finite amount of nonrenewable resources (low-entropy biomass); (2) the eco-system has a finite capacity

19 For the complete review of Deutsche Bank's social initiatives please refer to http://www.db.com/csr/index_e.htm or consult Corporate Social Responsibility Report 2008: http://www.db.com/csr/en/download/DBF_CSR08_EN_72dpi.pdf [Retrieved 12-11-2009].

20 Josef Ackermann, Deutsche Bank corporate social responsibility report 2008, http://www.db.com/csr/en/download/DBF_CSR08_EN_72dpi.pdf, 2 [Retrieved 12-11-2009].

${ }^{21}$ Herman Daly, "Economics in a full world", Scientific American 9 (2005): 78. 
to absorb pollution and waste; (3) there is limited space in which renewable resources like food and timber can be recreated and in which waste can be discarded.

What we should never loose from sight is that man cannot create matter. He merely rearranges it in production from what he takes from the biosphere. The only think we can do is to add to natural materials a useful structure which economists call added value. Nevertheless, what happens in consumption is that we use up not only the added value, but also the inner, natural value of matter or energy. Were we to consume only what we added in production, the natural materials would constitute an indestructible base that could be loaded with added value again and again. But this is not true. When we use up petrol, for instance, we do not consume only that utility added in production, but also its base, namely crude oil itself. As a result, we cannot consume the same share of petrol again and again. We always need fresh inputs from the natural base.

Besides the scarcity of natural sources and sinks, human economic activity is limited by the second law of thermodynamics, also known as the conservation law of matter and energy. This law tells us that there are objective limits to technological efficiency. The second law of thermodynamics ascertains that energy can be either created or disappear. The biomass passes from high energy-intensive states (low entropy) to low energy-intensive states (high entropy). A practical implication is that an economic system (production-consumption) cannot be separated from its natural base, because the matter/energy that is used is constantly used up. The economy has a constant need of new inputs of low-entropy matter/energy. Such inputs cannot be created from nothing.

What happens in the economic circle of production and consumption is that "we transfer matter from organised, structured, concentrated low-entropy states (raw materials) into still more highly structured commodities, and then through use into dispersed randomised, high-entropy states (waste)". ${ }^{22}$ In a strictly physical sense we either create or destroy things, but we transform them or rearrange law materials from low entropy state to high entropy state, and "there is limit to how much disorder can be produced in the rest of the biosphere without inhibiting its ability to support the human subsystem".23

Man-made economy is called a "dissipative structure" 24, for it is a complex and dynamic system which in order to maintain its internal order and escape gradual decay has a need of fresh entries of low entropy matter/energy. It seems that the

\footnotetext{
${ }^{22}$ Herman Daly, Steady-state economics. The economics of biophysical equilibrium and moral growth (San Francisco: W.H. Freeman \& Company, 1977), 22.

${ }^{23}$ Herman Daly, Steady-state economics..., 24.

${ }^{24}$ William E. Rees, "Revisiting carrying capacity: area-based indicators of sustainability", in A.R. Chapman - R.L. Petersen - B. Smith-Moran (edd.), Consumption, population and sustainability. Perspectives from science and religion (Covelo: Island Press, 2000), 75.
} 
man-made economy stays "alive" owing to increasing entropy in the ecosystem. In the ultimate instance the economy depends on linear, unidirectional thermodynamic flows of biomass from low-entropy states to high-entropy states.

The second law of thermodynamics assures that "all physical processes, natural and technological, proceed in such a way that availability of the energy involved decreases". 25 Consequently, the economy cannot be a perpetum mobile enterprise because it is constrained by finite resources. "The economic process is solidly anchored to a material base which is subject to definite constraints" ${ }^{26}$

A sincere recognition of these biophysical limits to economic practices provides a rationale for environmental sustainability - a resourceful use of natural capital and elimination of pollution ${ }^{27}$. Generally speaking, we can distinguish two different pathways towards environmental sustainability. One is eco-efficiency; the other is bioimitation.

Eco-efficiency implies doing more with less. It is using less material and energy to obtain a certain product or service. However, eco-efficiency can only make our industrial practices less harmful, but not harmless. It has a strictly mitigating character. It is designed to curb the amount of generated waste and pollution, but not to eliminate it. The role of eco-efficiency is to alleviate the noxious side-effects of the conventional cradle-to-grave scheme of production and consumption, and not to overcome the scheme. Eco-efficiency follows the $3 R^{\prime}$ s rule inasmuch as it implies

${ }^{25}$ P.R. Ehrlich - A.H. Ehrlich - J.P. Holdren, "Availability, entropy, and the laws of thermodynamics", in H.E. Daly - K.N. Townsend (edd.), Valuing the Earth. Economics, ecology and ethics (CambridgeLondon: The MIT Press, 1996),

${ }^{26}$ P.R. Ehrlich - A.H. Ehrlich - J.P. Holdren, "Availability, entropy, and the laws of thermodynamics", in H.E. Daly - K.N. Townsend (edd.), Valuing the Earth. Economics, ecology and ethics (CambridgeLondon: The MIT Press, 1996), 71.

27 The criterion of environmental sustainability derives from the principle of the universal destination of goods (Cf. Compendium of the Social Doctrine of the Church, n.171) and the moral duty to safeguard the environment (Cf. Compendium of the Social Doctrine of the Church, n.466). The earth and its resources are a free gift of the Creator to the whole human race, both present and future generations. A healthy environment is indispensable for a good life and economic prosperity. Therefore we have a moral duty to safeguard the biosphere, which is a common good of mankind, without favouring or excluding anyone. In particular, the Social Doctrine of the Church encourages economic agents to take into account the integrity and natural cycles of the biosphere because natural resources are limited and some are not renewable (Cf. Compendium of the Social Doctrine of the Church, n.470). It underscores that the contemporary environmental crisis is due to an erroneous conception that an infinite quantity of energy and resources are available and that negative effects of the exploitation of the natural order can be easily absorbed (Cf. Compendium of the Social Doctrine of the Church, n.462). 
reduction of waste, reuse of soil, water, paper and other raw materials, and restoration of industrial sites ${ }^{28}$.

Bio-imitation however means that human industry and architecture should imitate solutions and design that are present in the natural world. Most fundamentally, biomimicry implies the elimination of industrial and consumer waste, which becomes food for other processes. Instead of mitigating environmental damage and restoring ecological health, we can avoid environmental costs by imitating the laws of nature and copying biologically intelligent design in the processes of production, consumption and architecture. We can run a business like a self-sustaining biological ecosystem that produces a marginal amount of waste and few harmful effects. We can also use nature as a guide to develop new products by translating technical solutions present in nature into business reality. As in nature, so in manmade industries materials can circulate in closed-loop cycles: (1) in a biological loop biodegradable and bio-compatible materials; and (2) in a technological loop - nonbiodegradable products, which should always stay outside the biological world. Bioimitation is the basis of a cradle-to-cradle economy - "an ecologically intelligent approach to architecture and industry that creates materials, buildings and patterns of settlement that are wholly healthful and restorative". ${ }^{29}$

For example, Dow Chemical Company started rent a solvent campaign. The company offers a chemical that serves to remove grease from industrial equipment. In fact, the company does not sell the solvent, but it provides a degreasing service. It leases the grease-removing chemical to customers, then it takes back grease, separate used solvent from grease and resell the solvent. BASF Company created an eco-effective carpet material called SAVANT. Carpets made of SAVANT can be dyed on demand. The material is stain resistant and inherently colourfast. Carpets are leased for a defined period and then retrieved from customers to be remanufactured. Built-e Inc is a US-wide supplier of sustainable building materials and hardware. The company offers organic wool carpets, non-toxic paints and insulation made from recycled denim. Humanscale produces ergonomic office products, especially desks and chairs. As a comparison, a certain model of office chair by Humanscale consists of 132 parts, while a similar model from the competition can contain up to 278 parts. Pangea is an organic line of body products that are not harmful to the environment. Pangea body products have been equipped with biodegradable containers that can be thrown to the yard when empty.

\footnotetext{
${ }^{28}$ Cf. P. Hawken - A. Lovins - L.H. Lovins, Natural capitalism. Creating the next industrial revolution (Boston-New York-London: Little, Brown \& Company, 1999).

${ }^{29} \mathrm{~W}$. McDonough - M. Braungart, "Toward a sustaining architecture for the $21^{\text {st }}$ century", Industry and Environment vol.26, no. 2-3 (2003): 23; Cf. W. McDonough - M. Braungart, Cradle to cradle. Remaking the way me make things (New York: North Point Press, 2002).
} 
As far as cradle to cradle architecture is concerned, William McDonough + Partners design smart buildings with sustainable features. Such constructions accrue more energy then they consume, purify waste water, harvest rainwater, avoid heat dispersion, and are equipped with green roofs that create mild microclimate. William McDonough + Partners designed Nike's European headquarters in the Netherlands.

"A complex of five new buildings was designed to integrate the indoors with the surrounding environment, tapping into local energy flows to create healthy, beneficial relationships between nature and human culture. The buildings are organised around a central green and form four smaller courtyards around the perimeter, each landscaped with native plants. The orientation of the buildings and the window design maximise daylight while minimising heat gain. Ground-source heat pumps use the constant temperature of the Earth for heating and cooling. On the roofs, cisterns collect 3.9 million litters of storm water annually for landscape irrigation and other grey water uses. Outdoors there are volleyball, basketball and tennis courts; indoors, a bistro and restaurant, sunlight and copious fresh air. In short, it's an exceptionally pleasant place to work, to connect with colleagues and friends, to come to know the surrounding natural world-to find inspiration". ${ }^{30}$

\section{Conclusions.}

To talk about life together and interrelationships in business means to enter into the on-going, lively debate on corporate social responsibility. As I tried to argue above, there are good reasons to think that companies should adopt a sense of social rootedness insofar as "the familiarity of companies with the local actors and the local environment is an asset from which they capitalize". ${ }^{31}$ Corporate exuberance seems indissoluble linked to welfare of communities. This is why firms should have an interest in promoting symbiotic life together and mutually beneficial interrelationships with various stakeholders.

What even more, corporate social responsibility may help people in business to grow as human persons because it keeps them connected to the outside world around them. Corporate social activity, for example employee volunteerism, feeds your sense of compassion, sympathy and benevolence while you assist others.

At the same time however we should take into account that financial consequences of corporate social activism are uncertain; the implementation of corporate social responsibility policies entail significant costs; and the extent of corporate responsibility is not clearly defined. Although life together and

\footnotetext{
30 W. McDonough - M. Braungart, "From inspiration to innovation-Nike", http://www.mcdonough.com/writings/inspiration_innovation.htm [Retrieved 20-04-2006].

${ }^{31}$ M. Benioff - K. Southwick, Compassionate capitalism. How corporations can make doing good an integral part of doing well (New Jersey: Career Press, 2004), 207-208.
} 
interrelationship seem to be praiseworthy ideals that guide the functioning of companies, it is hard to say how much we can justly expect from business in terms of social responsibility. ${ }^{32}$

The latest encyclical of Benedict XVI Caritas in veritate adds another layer of difficulty to already difficult discourse on corporate social responsibility. While on the one hand companies have hard time escaping the so-called "race to the bottom" which obliges them to cut costs and spending in order to remain competitive, on the other hand the encyclical invites them to practice economy of communion and fraternity. ${ }^{33}$ It certainly is a great challenge to enrich normal economic activity with the principle of gratuitousness and the logic of gift. ${ }^{34}$ Yet, in the aftermath of the 20082009 economic crises, it remains even clearer that "management cannot concern itself only with the interests of the proprietors, but must also assume responsibility for all the other stakeholders who contribute to the life of the business: the workers, the clients, the suppliers of various elements of production, the community of reference" ${ }^{\prime \prime} 35$

\footnotetext{
${ }^{32} \mathrm{Cf}$. The Norwegian Ministry of Foreign Affairs, Corporate social responsibility in a global economy.

${ }_{33}$ Cf. Benedict XVI, Encyclical Letter Caritas in Veritate on integral human development in charity and truth, n.34-42.

${ }^{34}$ Cf. Benedict XVI, Caritas in veritate, n.37.

${ }^{35}$ Cf. Benedict XVI, Caritas in veritate, n. 40 .
} 


\section{Bibliography}

Aa.Vv., "The battle for brainpower. A survey of talent", The Economist 40 ( $7^{\text {th }}-13^{\text {th }}$ October 2006).

Benedict XVI, Encyclical Letter Caritas in Veritate on integral human development in charity and truth (2009).

Benioff M. - Soutwick K., Compassionate capitalism. How corporations can make doing good an integral part of doing well (New Jersey: Career Press, 2004).

Chapman A.R. - Petersen R.L. - Smith-Moran B. (edd.), Consumption, population and sustainability. Perspectives from science and religion (Covelo: Island Press, 2000).

Daly H.E., “Economics in a full world”, Scientific American 9 (2005), 78-81.

Daly H.E., Steady-state economics. The economics of biophysical equilibrium and moral growth (San Francisco: W.H. Freeman \& Company, 1977).

Daly H.E. - Townsend K.T. (edd.), Valuing the Earth. Economics, ecology and ethics (Cambridge-London: The MIT Press, 1996).

European Commission, Directorate General for Employment and Social Affairs, Promoting a European framework for corporate social responsibility - Green Paper (Luxembourg, 2001).

George P., "Making business moral”, The First Things 186 (October 2008), 17-19.

Hawken P. - Lovins A. - Lovins L.H., Natural capitalism. Creating the next industrial revolution (Boston-New York-London: Little, Brown \& Company, 1999).

John Paul II, Encyclical Letter Centesimus Annus (1991).

McDonough W. - Braungart M., Cradle to cradle. Remaking the way me make things (New York: North Point Press, 2002).

Norwegian Ministry of Foreign Affairs, Corporate social responsibility in a global economy. Report no. 10 (2008-2009) to the Storting (Oslo, 2009).

Solomon R.C., Ethics and excellence. Co-operation and integrity in business (New York - Oxford: Oxford University Press, 1993). 


\section{E- LOGOS}

ELECTRONIC JOURNAL FOR PHILOSOPHY

Ročník/Year: 2010 (vychází průběžně/ published continuously)

Místo vydání/Place of edition: Praha

ISSN 1211-0442

Vydává/Publisher:

Vysoká škola ekonomická v Praze / University of Economics, Prague

nám. W. Churchilla 4

Czech Republic

13067 Praha 3

IČ: 61384399

Web: http://e-logos.vse.cz

Redakce a technické informace/Editorial staff and technical information:

Miroslav Vacura

vacuram@vse.cz

Redakční rada/Board of editors:

Ladislav Benyovszky (FHS UK Praha)

Ivan Blecha (FF UP Olomouc)

Martin Hemelík (Masarykovo klasické gymnázium, Říčany u Prahy)

Angelo Marocco (Pontifical Athenaeum Regina Apostolorum, Rome)

Jozef Kelemen (FPF SU Opava)

Daniel Kroupa (ZU Plzeň)

Vladimír Kvasnička (FIIT STU Bratislava)

Jaroslav Novotný (FHS UK Praha)

Jakub Novotný (Vysoká škola polytechnická, Jihlava)

Ján Pavlík (editor-in-chief) (VŠE Praha)

Karel Pstružina (VŠE Praha) 